\title{
Lawful and Unlawful Acts in the System of Legal Facts of Penal Law: Theory of the Issue
}

\author{
EGOR E. NOVIKOV \\ University of FSIN Russia, Saint Petersburg, Pushkin, Russian Federation \\ ORCID: https://orcid.org/0000-0003-1556-1364, e-mail: mavr-85@mail.ru
}

\begin{abstract}
Introduction: the article considers lawful and unlawful acts as major types of legal facts that influence the functioning of penal relations. In the theory of law, these legal phenomena have remained virtually outside the scope of scientific attention; such a situation is contrary to the needs of penal science and application practice. Aim: by analyzing lawful and unlawful acts, we seek to identify features, signs and internal content of these legal facts, to identify issues related to enacting the analyzed legal phenomena in the norms of law, and to determine ways to address these issues. Methods: comparative legal method, empirical methods of description and interpretation; theoretical methods of formal and dialectical logic, interpretation of legal norms. Results: the analysis of lawful acts allowed us to identify their features, internal content and recommendations for their consolidation. Having studied unlawful acts, we were able to consider the essence, types and features of objectively illegal acts committed by convicts. Conclusions: when studying lawful acts, we formulated a conclusion that the legislator should exclude lawful omission where it "intersects" with the obligation of the subject of penal legal relations to act (when the right of the subject is, in fact, their duty). The article summarizes, that the commission of an objectively illegal act by the convict should not be the basis for bringing them to liability. Legal facts that indicate a different (not objectively illegal) delinquent behavior of a convict, regardless of its type, should entail that the convict be held liable mandatorily. However, the legislator does not record these infringing legal facts in the chapters that regulate the execution and serving of sentences in the form of deprivation of the right to hold certain positions or engage in certain activities, in the form of arrest and all types of punishments intended for military personnel; all this, we believe, significantly complicates the development of penal legal relations.

Ke y w ord s: legal facts; lawful acts; unlawful acts; penal legal relations; objectively illegal acts; unlawful omission; lawful omission.
\end{abstract}

12.00.08 - Criminal law and criminology; penal law.

For c it a ti o n: Novikov E.E. Lawful and unlawful acts in the system of legal facts of penal law: theory of the issue. Penitentiary Science, 2021, vol. 15, no. 2 (54), pp. 387-395. DOI 10.46741/2686-9764-2021-15-2-387-395.

\section{Introduction}

The theory of legal facts does not belong to the new branches of legal science; pre-revolutionary and Soviet jurisprudence, legal scholars of modern Russia [3; 6; 15; 19] and foreign countries tried to tackle problems related to facts [16-18].

Nevertheless, noting a high level of scientific elaboration on the theory of law, we have to admit that the facts that influence the functioning of penal relations have remained outside the scope of scientific attention; such a situation does not satisfy the needs of penal science and application practice. Only some legal schol- ars, namely N.M. Ibragimova, N.I. Polishchuk, V.I. Pinchuk, A.S. Sevryugin, have produced thorough answers to a number of specific issues concerning the legal phenomena under consideration.

We should note that the norms of penal law contain both lawful and unlawful legal acts, which can be divided into actions and omissions.

Lawful and unlawful actions and omissions as legal facts that influence the functioning of penal legal relations.

The legality of an act of the subjects of penal legal relations determines the presence of 
permission, obligation or prohibition of certain behavior in law. In other words, a legitimate legal action/omission will be the active/passive behavior of legal entities that implement the norms of permission, obligation and prohibition established by law.

Revealing the features of lawful actions of the subjects of penal legal relations, we note that they are aimed at the use of permissive norms and execution of binding norms (fig. 1). Proceeding from the viewpoint of N.G. Aleksandrov, who consolidates "possible behavior and required proper behavior in legal norms... in the form of models of legal subjective rights and legal obligations" [13, p. 541], the legislator directs the activities of the subjects of legal relations toward achieving the goals set out in the penal legislation.

Lawful legal facts-actions of the subjects of penal legal relations with the use of permissive norms comply with the following requirements (features):

- the emergence of these legal facts should not be driven by the compulsion of the subject of the legal relationship to implement permissive regulations;

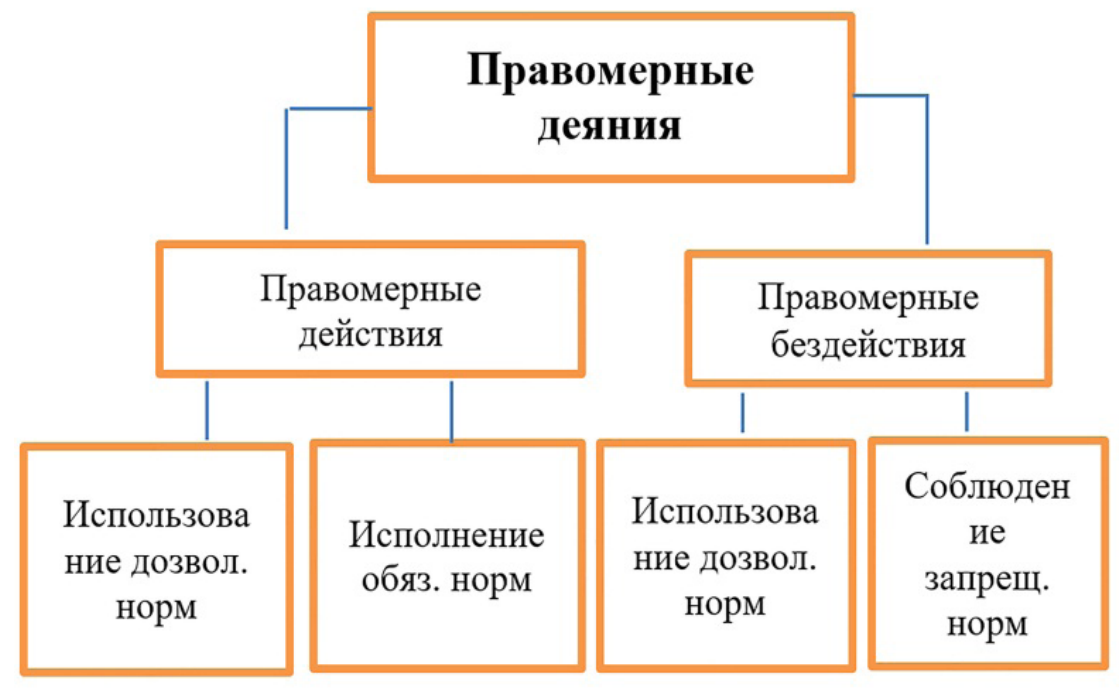

Figure 1

Правомерные деяния - Lawful acts; Правомерные действия - Lawful actions; Правомерные бездействия - Lawful omissions; Использование дозволяющих норм - Use of permissive norms ; Исполнение обязывающих норм - Exесиtion of binding norms; Соблюдение запрещающих норм - Compliance with prohibiting norms

- the refusal of the subject of law to use the considered facts and actions should not contribute to bringing the participant of a penal legal relationship to any type of liability;

- the subject of penal legal relations should be able to implement lawful facts-actions without hindrance;

- these legal facts should entail the emergence of the following possibilities for the authorized subjects of penal legal relations: 1) to enjoy material or spiritual benefits and/or 2) to require other persons to perform actions that correspond to the content of the legal fact and the relevant legal relationship.

The features inherent in legitimate legal facts-actions and based on the execution of binding norms by the subjects of law are qualitatively different from those discussed above. These features include the following:

- the subject of penal legal relations should initiate the occurrence of a given legal fact-ac- tion regardless of their personal attitude toward the actions performed and the legal relations they may generate;

- the refusal of the subject to perform legitimate legal facts-actions based on the implementation of binding norms should ensure that the subject of penal legal relations be brought to liability mandatorily;

- the performance of these legal facts-actions may or may not satisfy the interests and needs of the persons who perform them (for example, when a convict sentenced to imprisonment arrives at their workplace, this fact may or may not represent a legitimate legal fact-action that generates legal relations satisfying the interests and needs of the convict).

These legal facts are represented in penal law by a large number of legal prescriptions. Thus, if a convict purchases foodstuffs (Article 88 of the RF Penal Enforcement Code) then the fact of purchase, which is aimed at imple- 
menting the rights of the convict (i.e., norms of permission) to obtain ownership, will be legally significant; and the actions of an individual, which are associated with compensation for the damage (Article 102 of the RF Penal Enforcement Code) inflicted on the correctional facility, constitute a legal fact that supports the corresponding binding norm.

We believe that a lawful action does not involve the use of prohibiting norms, since they declare that the subject should not perform certain actions defined in the law: the behavior of an individual who violated the requirement that proceeds from a prohibiting norm cannot be called a lawful action.

Lawful legal facts-omissions influence legal relations focused on compliance with prohibitive norms and the use of permissive norms.

Previously, penal science has not focused on analyzing lawful omission as a legal fact. But, according to the study of legal doctrine, we can conclude that in a limited number of works it allows for the existence of lawful omission. Thus, according to the opinion of V.N. Kazakov, lawful omission is the behavior of subjects of law that is aimed at "... the implementation of the vast majority of prohibitive norms..." [3, p. 20].

It is difficult to overestimate the importance of lawful legal facts-omissions focused on compliance with prohibiting regulations. We agree with N.N. Rybushkin, who points out that "while complying with prohibiting norms, subjects of law in a way separate themselves from displacing relations and do not enter into them" [12, p. 17].

For example, convicts serving sentences in the form of corrective labor are prohibited from resigning voluntarily (Part 3 of Article 40 of the RF Penal Enforcement Code); the administration of the correctional institution must not use convicts to perform the works (e.g., maintenance and repair of technical means of protection and supervision, etc.) established by the internal regulations of the correctional institution (Order of the Ministry of Justice of the Russian Federation no. 295 dated December 16, 2016). Passive conduct in the above examples is socially useful, necessary and required, and it plays a positive role and serves as a condition for the normal functioning of penal legal relations. The subjects avoid conflicts and take into account public interests by observing the prohibitions aimed at preventing possible implications that are undesirable for society, the state, and individuals [10, p. 159].
The conduct of the subjects of penal legal relations that are connected with the non-use of permissive norms can also be a lawful legal fact-omission that affects penal legal relations.

V.N. Kudryavtsev spoke about the obligation to distinguish lawful omission. However, he rightly notes that in some cases the benefits of non-implementation of permissive norms are questionable. The researcher argues that "if compliance with prohibitions does not arouse doubt from the point of view of usefulness and adequacy", then the second type of lawful omission, "consisting in the non-use of one's right", is heterogeneous" [4, p. 137]. In other words, the omission of the subjects of penal legal relations who do not use permissive regulations is not always necessary, justified and useful.

We can provide the following examples of legal facts-omissions, which on the one hand are lawful and on the other - questionable and hindering normal functioning of penal legal relations:

- when a convicted person serving a sentence in the form of corrective labor or imprisonment does not apply to the authorities of the penitentiary institution with a statement about ensuring his/her personal safety (Part 2 of Article 13 of the RF Penal Enforcement Code). According to $76 \%$ of surveyed staff of pre-trial detention facilities and correctional facilities, it is not always possible to eliminate threats to personal safety in a timely manner if there is no application from the convicted individual;

- we agree with the opinion of the majority of staff of probation inspectorates (82\%) who noted that the cases when pregnant convicts do not appeal to the court with a petition for suspension of sentence in the form of compulsory labor (Part 3.1 of Article 26 of the RF Penal Enforcement Code) or corrective labor (Part 5 of Article 42 of the RF Penal Enforcement Code) negatively affect the relations in the sphere of execution and serving criminal sentences;

- the cases when ill convicts sentenced to compulsory labor (Part 3 of Article 26 of the RF Penal Enforcement Code) or corrective labor (Part 4 of Article 42 of the RF Penal Enforcement Code) do not appeal to the court for exemption from punishment due to the fact that they have a severe disease also affects penal relations.

Thus, the refusal of convicts to use their rights in some cases negatively affects the development of penal legal relations, but the person bears no responsibility for such conduct. 
Penal legislation contains similar legal factsomissions (i.e., facts based on the non-use of a right, but generating negative implications) that illustrate the conduct of agents executing criminal penalties (measures), for example, when prison staff do not use incentive measures such as rewards in relation to convicts when there is sufficient reason to do so: "... good demeanor, conscientious attitude toward labor and education, active participation in educational activities" (Paragraph 1 of Article 113 of the RF Penal Enforcement Code).

However, it would be fair to note that most often the above-mentioned omissions on the part of prison staff not only have a negative impact on the development of penal legal relations, but can also be the basis for bringing them to justice. This happens when the right of the subjects of legal relations is, in fact, their official duty. In this case an individual cannot refuse to exercise the right enshrined in the law. Otherwise, the omissions of participants of legal relations based on these specific rules would be a legal fact, which gives rise to legal liability. Considering this phenomenon, V.N. Kudryavtsev notes that in order to avoid a negative outcome, law enforcers should answer the following question: does the use of their rights coincide with the non-fulfillment of their duties? [4, p. 137].

In penal law, one can distinguish an extensive list of legal facts that have a similar dual nature:

- prison administration may not waive its right to perform inspection of persons, their belongings, and vehicles in the territory of the prison and its adjacent areas that are under the requirements of the regime, and may not waive its right confiscate prohibited items and documents (Part 6 of Article 82 of the RF Penal Enforcement Code);

- prison administration may not waive its right to use audio-visual, electronic, or other technical means of supervision and control to prevent jailbreaks and other violations of law (Part 1 of Article 83 of the RF Penal Enforcement Code), etc.;

The considered coincidence of the use of one's rights with the performance of one's duties in penal law is found only in subjects who execute criminal penalties (measures).

We should note that the presence of such norms in penal law may lead to their incorrect interpretation by practitioners and to subsequent omissions, which negatively affect the functioning of penal legal relations. This thesis is confirmed by the results of a survey of prison staff, $22 \%$ of which indicated that the staff may not apply penalties (!) to the convicts in case they committed a violation, since it is the right of the staff, rather than their obligation.

It is possible to find a solution to this issue, first, not only through legal education (as V.N. Kudryavtsev points out), but also by revising the content of such norms. Thus, we believe that it is possible to eliminate negative implications of lawful omissions, which arose after an ill convict sentenced to compulsory labor had not submitted an appeal for exempting them from serving their sentence, if correctional institutions will have the right to petition the court for the convict's exemption.

Second, if the legislator transfers certain rights into the category of duties, it would also help eliminate some negative omissions. For example, Part 6 of Article 82 of the RF Penal Enforcement Code must contain a statement that prison administration has not the right, but the obligation, to perform inspection of persons, their belongings, and vehicles in the territory of the prison and its adjacent areas that are under the requirements of the regime, and confiscate prohibited items and documents, the list of which is established by the legislation of the Russian Federation and internal regulations of correctional institutions.

It is necessary to emphasize that not every lawful omission should be considered as a legal fact. It can be considered as such if it does not have a direct impact on the functioning of penal legal relations, if it is not legally significant, i.e. does not generate, change, suspend or terminate legal relations. For example, if a convict does not use their right to phone calls, it is a lawful omission, but not a legally significant fact, since it does not affect the functioning of any penal legal relations.

Lawful omission includes such legal facts that can only act as elements of the actual composition. In penal law, omission, in the absence of its connection with other legal facts, will not give rise to legal relations. But this does not diminish the role of the conduct under consideration, since each of the elements of the actual composition is important in its own way and has an independent significance.

Let us consider the following example: penal legal relations connected with a convict being transferred from the medium security prison to a relaxed security prison will not occur if there are no facts to which the legislator has attached legal value by enshrining them in law: the lack of penalties for violations of the established order of serving the sentence, and conscientious at- 
titude toward work (Part 2 of Article 120 of the RF Penal Enforcement Code).

In this case we are interested in the absence of penalties for violation of the established order of serving a sentence, which may be formed only if there is a legal symbiosis between the lawful action and compliance with binding norms (conscientious attitude toward labor) and the lawful omission oriented toward observance of the norms that prohibit, for example, consumption of alcoholic beverages or narcotic drugs or psychotropic substances, disobedience to prison administration, gatherings of convicted persons for the purpose of committing offenses, etc. In this case, lawful omission will be a legal fact, the mandatory presence of which entails the formation of appropriate penal legal relations.

Speaking about unlawful acts (fig. 2), first of all, we should note that the theory of law clas- sifies unlawful conduct into objectively illegal acts and infringing legal facts.

Despite obvious interest of legal scholars such as S.S. Alekseev, V.B. Isakov, S.I. Samishchenko, A.M. Khuzhin to objectively illegal acts, this issue has not become a subject of thorough research in Russian science. We agree with I.A. Minnikes [6, p. 19], who notes that the situation in educational literature is largely similar: only some textbooks on the theory of state and law mention this type of acts. Penal science is not an exception, because it has not considered the issues of objectively illegal conduct as a legal fact at all.

Almost all representatives of legal science who classify unlawful acts into these two types note that objectively illegal conduct is an illegal, disapproved, harmful, but crimeless act, which is expressed in non-fulfillment of legal obligations and non-compliance with prohibitions [1, p. 353].

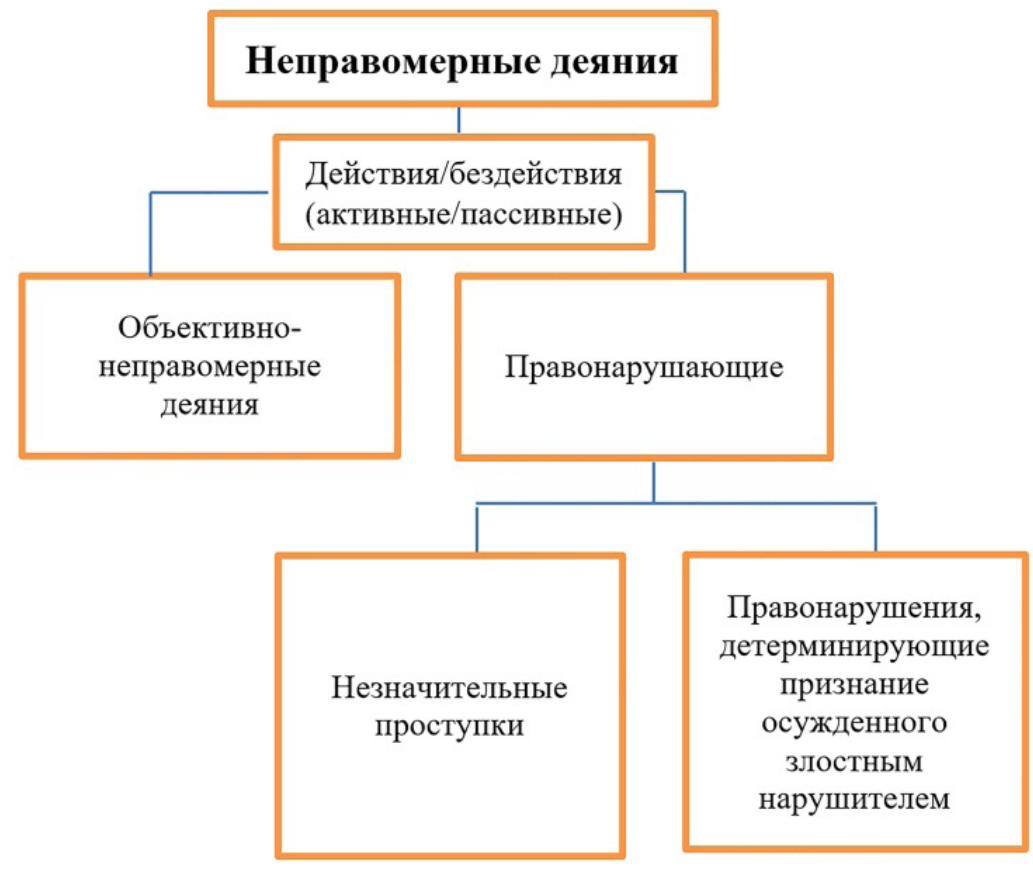

Figure 2. Unlawful acts

Неправомерные деяния - Unlawful acts; Действия/бездействия (активные/пассивные) - Actions/omissions (active/ passive); Объективно-неправомерные деяния - Objectively unlawful acts; Правонарушающие - Infringing; Незначительные проступки - Minor offences; Правонарушения, детерминирующие признание осужденного злостным нарушителем Offences determining the recognition of a convict as persistent offender

Objectively illegal acts contained in penal law can be divided into two groups:

1) the first group should include objectively illegal acts that are contained in penal law, but the legal relations they affect are outside the scope of the subject of penal legal regulation. These are "classic" legal facts of this kind, and they are contained in the legislation under consideration in a limited number. They can, for example, include crimeless infliction of material damage on the correctional center by the convict (Part 2 of Article 60.20 of the RF Penal Enforcement Code) or unintended infliction of bodily self-harm (Part 2 of Article 102 of the RF 
Penal Enforcement Code). First of all, the group includes acts that have resulted in work-related accidents and injuries. For example, in 2018, the number of convicts who were injured at work amounted to 228 people [8, p. 60].

2) the specific feature of the second group of legal facts is that they have a direct impact on the legal relations functioning in the sphere of execution and of criminal penalties (measures). These legal facts include objectively illegal acts, which are such due to the presence of "... a certain reason that prevented the convicted person from fulfilling the requirements defined by law" [11, p. 118]. We are talking about viable reasons, the presence of which excludes the possibility of bringing a person to justice for committing an unapproved act. As an example, let us look at the following objectively illegal acts, which are considered as such in connection with valid reasons: absence from compulsory work for more than two times during the month (Part 1 of Article 30 of the RF Penal Enforcement Code); non-compliance of the convict, who is sentenced to incarceration, with restrictions established by the court (Item "b" of Part 1 of Article 58 of the RF Penal Enforcement Code); failure of the convict to visit a probation inspectorate to undergo registration (Item " $g$ " of Part 1 of Article 58 of the RF Penal Enforcement Code) [7, p. 45-51]; refusal to work or stoppage of work (Part 1 of Article 116 of the RF Penal Enforcement Code), etc.

Acts included in both groups possess all the features inherent in objectively illegal conduct.

First, the formal sign of such behavior is illegality, which is expressed in violation of the norms of law. The behavior of a convicted person is illegal if it does not meet the requirements of binding or prohibiting norms. For example, infliction of material damage on the correctional facility or infliction of bodily self-harm violate the provisions of federal legislation (Part 2 of Article 11 of the RF Penal Enforcement Code) and by-laws, which state that the convicted person is obliged to "take care of the property of the correctional facility and other types of property" (Item 15 of Section IV of the Order of the Ministry of Justice no. 329 dated December 29, 2016) and not to inflict "bodily self-harm" (Item 17 of Section III of the Order of the Ministry of Justice no. 295 dated December 16, 2016).

Second, the objectively illegal acts that we are considering in this paper are committed guiltlessly, i.e. the person does not realize and cannot realize the illegality of their actions due to the circumstances of the case, or does not foresee the possibility of negative implications and cannot and should not have foreseen them due to the circumstances of the case [4, p. 62], or cannot prevent the occurrence of negative consequences due to the presence of exceptional circumstances. We believe that the legislator, when determining the category of "viable reason", assumes that the convicted person, according to the general rule, is aware of and anticipates the onset of consequences, but the presence of exceptional circumstances does not allow them to fulfill the duty or comply with the prohibition.

Third, such behavior has a negative impact on the functioning of correctional institutions and causes harm.

Fourth, since they are legal facts, the objectively illegal acts cannot but affect the functioning of legal relations. The first group of legal facts, as we have already noted above, affects the functioning of legal relations that are outside the scope of penal legal regulation. The objectively illegal acts that belong to the second group of legal facts generate, change or terminate legal relations that are directly influenced by the norms of penal law.

Fifth, a convicted person, having committed an objectively illegal act, may refrain from participating in the restoration of the violated penal relations, and may not be held liable (note: we share a viewpoint of some legal authors who state that in some cases objective liability takes place in legal relations regulated by state civil (private) and international law. See, for example: [5, p. 44]). In this context, we agree with A.M. Khuzhin [14, p. 20; 15], who notes that an individual should be held liable only for the commission of an offense that includes all the components inherent in misconduct, including such component as guilt.

The convict's volitional conduct that interferes with the normal functioning of penal legal relations is an infringing legal fact that entails bringing the convict to disciplinary liability. We share the opinion of L.I. Petrazhitskii, who points out that "illegal and prohibited actions are such actions or omissions that are contrary to the requirements ("dictates") of the law and lead to known (unprofitable for the violator) legal implications, for example, an obligation to compensate for the damage caused or to suffer punishment" [2, p. 361].

The presence of these legal facts indicates the non-performance or improper performance of binding norms and non-compliance with the prohibiting prescriptions. Proceeding 
from the content of this statement, we can distinguish three groups of legal facts that indicate the convict's infringing conduct:

1) non-performance of duties. These legal facts, compared to the other two, are represented in penal legislation in the greatest number; it is for a reason, since the legislator focuses more on formalizing in the RF Penal Enforcement Code those duties of convicts, the non-execution of which entails the emergence, change or termination of penal relations;

2) improper performance of duties. These legal facts in their legal nature are as similar as possible to those discussed above. However, their presence indicates that the convict de jure did not refuse to perform the prescribed duty, but performs it carelessly, untimely, incorrectly, inaccurately, and not in full. According to the staff of correctional facilities, legal facts of this kind can include, for example, failure to keep one's sleeping place and working place tidy and in order, failure to observe personal hygiene rules in full, etc. In the above examples convicts do not refuse to perform the established duties, rather, they do not fulfill them to the fullest extent.

3) non-compliance with prohibitions. The presence of this legal fact indicates that the purpose of the prohibition, which is to keep convicts from committing an unlawful act ("... and thereby achieve a conflict-free state of public relations" [11, p. 12]), has not been achieved.

The analysis of penal legislation proves that the failure of convicts to comply with prohibitions is what the legislator "condemns" more than other cases of their misdemeanor. In other words, the presence of a separate legal fact, as a general rule, is the basis for bringing a convict to a more serious type of liability; this is pronounced most clearly in the norms governing the execution and serving of custodial sentences. For example, all the acts stipulated in Part 1 of Article 116 of the Penal Enforcement Code of the Russian Federation (this part establishes the infringing conduct of a convict, for which they can be recognized as maliciously violating the established procedure for serving a custodial sentence) are legal facts emerging in connection with the violation of a prohibition.

Infringing legal facts can also be divided into two types: 1) minor offenses and 2) legal facts, that lead to recognizing the convict as maliciously evading serving a sentence (measure) and also as maliciously violating the established procedure for serving a sentence (this category should also include a legal fact that gives grounds for recognizing probationers as persons who systematically violate the requirements imposed on them).

The infringing legal facts that belong to the first group are convicts' acts that are condemned by law, but to a lesser extent. These legal facts, regardless of what type of punishment they characterize, contain the conduct that causes minor harm to penal legal relations. The convict is recognized as a "conventional" violator rather than malicious violator. However, if a convict commits the same offense again, then in a number of cases it leads to this legal fact being "transferred" to the second group.

For example, a one-time violation of work discipline by a person sentenced to compulsory labor is a legal fact that gives rise to legal relations in the field of recognizing a person as a violator of the conditions for serving the relevant sentence. This behavior is condemned, but it is recognized as insignificantly violating penal legal relations. But if the convict violates work discipline once again within a month, this will be the fact for recognizing the convict as maliciously evading compulsory works (Part 1 of Article 30 of the RF Penal Enforcement Code), which gives rise to legal relations in the sphere of replacing compulsory works with other kinds of punishment (Part 2 of Article 29 of the RF Penal Enforcement Code).

Legal facts with similar content can be also found in those chapters of the RF Penal Enforcement Code that regulate the execution (serving) of punishment in the form of corrective labor (Part 3 of Article 46 of the RF Penal Enforcement Code), incarceration (Part 4 of Article 58 of the RF Penal Enforcement Code), compulsory labor (Part 3 of Article 60.15 of the RF Penal Enforcement Code).

In addition, legal facts of the second group should include those infringing acts that significantly violate penal legal relations. Committing even one such act is the basis for the emergence of legal relations in the sphere of recognizing the convict as maliciously evading serving the punishment (measures) and as the worst offender of the established order of serving the sentence. Such legal facts include, for example, non-payment of the fine (Part 1 of Article 32 of the RF Penal Enforcement Code); concealment of the place of one's location (residence) (Item "c" of Part 1 of Article 30, Part 3 of Article 46, Item "c" of Part 4 of Article 58 of the RF Penal Enforcement Code), the convict's refusal to use technical means of supervision and control (Item "b" of Part 4 of Article 58 of the 
RF Penal Enforcement Code); consumption of alcoholic beverages, narcotic drugs or psychotropic substances (Item "a" of Part 2 of Article 60.15, Part 1 of Article 116, Part 7 of Article 178 of the RF Penal Enforcement Code); refusal to work or stoppage of work (Part 6 of Article 103 of the RF Penal Enforcement Code); all the acts contained in Part 1 of Article 116 of the RF Penal Enforcement Code, etc.

We should emphasize that there is no information on infringing legal facts in the chapters regulating the execution of and serving punishments in the form of deprivation of the right to hold certain positions or engage in certain activities, arrest and all types of punishments intended for military personnel.

We should note in brief that infringing legal facts, as well as lawful facts, can be expressed in the active and passive forms of conduct. An unlawful act and an unlawful omission can be oriented toward a refusal to fulfill binding norms or comply with prohibitory norms. For example, unlawful actions of a convict aimed at insulting prison staff should be accompanied by appropriate actions of the individual oriented toward the violation of a binding norm (Part 4 of Article 11 of the RF Penal Enforcement Code), and a convict's misconduct related to the consumption of alcoholic beverages, narcotic drugs or psychotropic substances (Part 1 of Article 116 of the RF Penal Enforcement Code) is evidence of an active refusal to accept a prohibitory norm.

An individual's failure to appear before the administration of the correctional institution can be called unlawful omission (Part 5 of Article 11 of the RF Penal Enforcement Code). In this case the convict violates a binding norm, and as for the passive behavior related to work stoppage aimed at resolving a labor dispute, it does not meet a requirement set out in the corresponding prohibitory norm (Part 6 of Article 103 of the RF Penal Enforcement Code).

\section{Conclusion}

Summing up, we find it necessary to make the following conclusions:

1. Lawful actions of participants of the legal relations under consideration are aimed at using permissive norms and complying with binding norms. At the same time, the features inherent in a lawful action based on the use of permissive norms and the features inherent in the execution of binding norms should be taken into consideration by the subjects of penal legal relations. In this regard, a lawful action does not imply the use of prohibiting norms, since according to this type of instruction the subject is not to perform certain actions defined by law: one cannot say that the behavior of an individual who violated a requirement that proceeds from a prohibiting norm is a lawful action.

Lawful legal facts-omissions influence the legal relations focused on observing prohibitory norms and complying with permissive norms.

2. The regulations that promote the emergence of a lawful omission where it intersects with the subject's obligation to act (when the right of the subject is, in fact, their duty) should be excluded from penal legislation.

3. Convicts' objectively illegal conduct should not entail their bringing to liability. However, objectively illegal conduct can generate other penal legal relations that proceed from the order of execution of a criminal penalty. For example, when a convict fails to arrive at a probation inspectorate to undergo registration, and there are valid reasons for this failure, then such a situation generates legal relations connected with checking the validity of this information, organizing additional supervision over the convict's behavior, and taking measures so as to prevent new cases of objectively illegal conduct on the part of the convict.

4. Legal facts of convicts' infringing conduct, regardless of their type (active/passive, insignificant/significant, based on non-performance of duties/ non-compliance with a prohibition), should entail liability. However, the legislator does not record these infringing legal facts in the RF Penal Enforcement Code in the chapters regulating the execution of and serving punishments in the form of deprivation of the right to hold certain positions or engage in certain activities, arrest and all types of punishments intended for military personnel, which, in our opinion, significantly complicates the development of penal legal relations.

\section{REFERENCES}

1. Alekseev S.S. Problemy teorii prava. T. 1. [lssues of the law theory. Volume 1]. Sverdlovsk, 1972. 396 p.

2. Antonyan A.G. Otsenochnye kategorii v ugolovno-ispolnitel'nom prave: dissertatsiya na soiskanie uchenoi stepeni doktora psikhologicheskikh nauk [Evaluation categories in penal law: Doctor of Sciences (Psychology) dissertation]. Tomsk, 2016. 232 p.

3. Kazakov V.N. Pravomernoe povedenie i pravoporyadok: dissertatsiya na soiskanie uchenoi stepeni doktora psikhologicheskikh nauk [Lawful behavior and legal order: Doctor of Sciences (Psychology) dissertation]. Moscow, 1999. 185 p. 
4. Kudryavtsev V.N. Pravovoe povedenie: norma i patologiya [Legal behavior: norm and pathology]. Moscow: Izdatel'stvo nauka, 1982. 289 p.

5. Kuz'min I.A. Objectively-illegal act as the basis of objective (innocent) responsibility. Vestnik Omskogo universiteta. Seriya: Pravo=Herald of Omsk University. Series "Law", 2011, no. 1 (26), pp. 39-44. (In Russ.).

6. Minnikes I.A. Objectively unlawful act. Rossiiskii yuridicheskii zhurnal=Russian Law Journal, 2008, no. 2 (59), pp. 19-23. (In Russ.).

7. Mursalimov K.A. Problematic aspects of proceedings in cases of administrative offenses in the activities of penal inspections. Obshchestvennaya bezopasnost', zakonnost' i pravoporyadok v III tysyacheletii=Public Safety, Lawfulness and Legal Order in the Third Millennium, 2018, no. 4, pp. 45-51. (In Russ.).

8. Osnovnye pokazateli deyatel'nosti ugolovno-ispolnitel'noi sistemy yanvar' - dekabr' 2018 g. Informatsionnoanaliticheskii sbornik [Key performance indicators of the penitentiary system for January - December 2018. Information and analytical collection]. Tver, 2018. 294 p.

9. Petrazhitskii L.I. Teoriya prava i gosudarstva $v$ svyazi s teoriei nravstvennosti [Theory of the law and state in relation with the theory of morality]. Saint Petersburg: Lan', 2000. 608 p.

10. Prusakov A.D. Deistvie i bezdeistvie kak formy yuridicheski znachimogo povedeniya: dissertatsiya na soiskanie uchenoi stepeni doktora psikhologicheskikh nauk [Action and omission as forms of legally significant behavior: Doctor of Sciences (Psychology) dissertation]. Saratov, 2008. 238 p.

11. Rad'ko T.N. Prohibiting norms in the mechanism of legal regulation. Vestnik Akademii prava $i$ upravleniya=Bulletin of Academy of Law and Management, 2018, no. 3 (52), pp. 9-17. (In Russ.)

12. Rybushkin N. N. Zapreshchayushchie normy v sovetskom prave [Prohibiting norms in the Soviet law]. Kazan: Izdatel'stvo Kazanskogo universiteta, 1990. $113 \mathrm{p}$.

13. Teoriya gosudarstva i prava [Theory of law and state]. Ed. by N.G. Aleksandrov. Moscow, 1974. 640 p.

14. Khuzhin A.M. Ob"ektivno-protivopravnoe povedenie v rossiiskom prave: avtoreferat dissertatsiya na soiskanie uchenoi stepeni kandidata yuridicheskikh nauk [Objectively unlawful behavior in the Russian law: Candidate of Sciences (Law) dissertation abstract]. Nizhny Novgorod, 2000. 23 p.

15. Khuzhin A.M. Ob"ektivno-protivopravnoe povedenie v rossiiskom prave: dissertatsiya na soiskanie uchenoi stepeni kandidata yuridicheskikh nauk [Objectively unlawful behavior in the Russian law: Candidate of Sciences (Law) dissertation]. Nizhny Novgorod, 2000. 158 p.

16. Bakirova E.Yu., Kuksin I.N., Lepeshkina O.V., Umarova A.A., Vlasenko N.A. Classification of jural facts in the legal system: experience of the legislation of the countries of the Commonwealth of Independent States. Talent Development and Excellence, 2020, vol. 12, no. 3, pp. 1311-1317.

17. Hage J. Dick W.P. Ruiter. Institutional legal facts: legal powers and their effects. Artificial Intelligence and Law, 1999, vol. 7 , no. 4 , pp. 377-385.

18. Ramm Th. Einfuhrung in das Privatrecht. Allgemeiner Teil des BGB. Munchen: Deutschen Taschenbuch, 1974. $916 \mathrm{p}$. 19. Voronin I.K. Ways of fixing legal facts in Roman law. Smart Innovation, Systems and Technologies, 2019, vol. 139, pp. 676-681.

\section{INFORMATION ABOUT THE AUTHOR}

EGOR E. NOVIKOV - Candidate of Sciences (Law), Associate Professor, associate professor of the Department of Criminal Law Disciplines, Faculty of Law, University of FSIN Russia, Pushkin, Saint Petersburg, Russian Federation. ORCID: https://orcid.org/0000-0003-1556-1364, e-mail: mavr-85@mail.ru

Received May 15, 2020 